\title{
PENYESUAIAN DIRI DALAM BEKERJA PADA PENGASUH DI PANTI ASUHAN CACAT GANDA: STUDI FENOMENOLOGIS
}

\author{
Dinni Asih Febriyanti, Anita Listiara, Y. F. La Kahija \\ Fakultas Psikologi Universitas Diponegoro \\ J1. Prof. Soedharto SH Tembalang Semarang 50275 \\ dinniasih@gmail.com
}

\begin{abstract}
The study was aimed to describe the work adjustment experience or orphan caregivers in orphanage for multiple disabilities (Panti Asuhan Cacat Ganda/PACG) using qualitative-phenomenology approach. The subjects were three caregivers working in PACG Semarang. Data were collected through semi-structured interview and observation. Data were then transcribed and analyzed to obtain psychological meaning, meaning units, concept map, and subjects' main experiences. The result shows that orphan caregiver work adjustment is the result of their decision to work at PACG. Work adjustment performed by those orphan caregivers consist of five form of adjustments i.e. the adjustment to caregiving, the adjustment to company's culture, the adjustment to interact with client, the adjustment to colleagues, and the adjustment to community. Subjects' work adjustment was influenced by some external and internal factors to build their coping strategies in order to overcome problems that arose during the adjustment. It may be concluded that caregiver's work adjustment is the synchronization of interpersonal relationship between caregiver and directors, clients, colleagues, and community.
\end{abstract}

Keywords: work adjustment, orphan care officer, orphanage, multiple disabilities, phenomenological

\begin{abstract}
Abstrak
Penelitian ini bertujuan untuk mendeskripsikan pengalaman penyesuaian diri pengasuh di Panti Asuhan Cacat Ganda (PACG) dengan menggunakan pendekatan kualitatif-fenomenologis. Subjek terdiri dari tiga orang pengasuh yang bekerja di PACG di Semarang. Metode pengumpulan data yang digunakan adalah wawancara semi terstruktur dan observasi. Data yang diperoleh kemudian ditranskripsi dan dianalisis untuk merumuskan makna psikologis, unit-unit makna, peta konsep, dan esensi pengalaman para subjek. Hasil penelitian menunjukkan bahwa penyesuaian diri para pengasuh merupakan konsekuensi dari pengambilan keputusan untuk bekerja di PACG. Penyesuaian diri para pengasuh dalam bekerja terdiri atas lima bentuk penyesuaian, yaitu penyesuaian terhadap tugas pengasuhan, penyesuaian terhadap budaya organisasi, penyesuaian dalam berinteraksi dengan kelayan, penyesuaian terhadap rekan kerja, dan penyesuaian terhadap masyarakat Usaha penyesuaian subjek dipengaruhi oleh sejumlah faktor internal dan faktor eksternal yang membentuk strategi koping mereka untuk mengatasi kesulitan selama melakukan penyesuaian tersebut. Esensi yang ditarik dari penelitian ini adalah penyesuaian diri pengasuh dalam bekerja pada intinya merupakan penyelarasan hubungan interpersonal antara pengasuh dengan pimpinan, kelayan, rekan kerja, dan masyarakat.
\end{abstract}

Kata Kunci : penyesuaian diri dalam bekerja, pengasuh, panti asuhan, cacat ganda, fenomenologis

\section{PENDAHULUAN}

Mengasuh penyandang cacat membutuhkan kesabaran dan kepedulian yang besar. Sebuah penelitian terhadap 468 ibu kandung yang mengasuh anak penderita cerebral palsy dari 19 pusat rehabilitasi anak di Ontario Kanada menunjukkan bahwa perilaku penyandang cerebral palsy dan tuntutan-tuntutan dalam pengasuhan (caregiving demands) merupakan dua faktor yang sangat berpengaruh terhadap kesejahteraan fisik dan psikologis para pengasuh (Parminder, dkk, 2005). Oleh karena itu dukungan sosial dari keluarga dan manajeman stres sangat dibutuhkan 
oleh para pengasuh tersebut agar dapat menjalankan tugas pengasuhan dengan baik. Hasil penelitian kuantitatif tersebut berbeda dengan kenyataan yang peneliti temukan ketika melakukan survei awal di Panti Asuhan Cacat Ganda (PACG).

Istilah panti asuhan dalam Kamus Besar Bahasa Indonesia (1995) didefinisikan sebagai rumah atau kediaman tempat memelihara dan merawat anak yatim atau yatim piatu. Istilah ini kemudian diasosiasikan dalam istilah panti asuhan cacat ganda yang dimaknai sebagai sebuah rumah atau kediaman untuk mengasuh dan merawat penyandang cacat ganda. Dalam bahasa Inggris, cacat ganda diungkapkan dalam istilah yang beragam antara lain double handicapped, multihandicapped (children), severe disabilities, multiple disabilities, severely handicapped, profoundly handicapped, dan severely multiple handicapped. Secara harfiah seluruh istilah tersebut diterjemahkan dalam bahasa Indonesia sebagai tuna ganda, cacat ganda, atau tuna majemuk. Istilah cacat ganda sebagaimana didefinisikan oleh Office of Education adalah kelainan-kelainan yang diderita anak secara bersamaan (seperti retardasi mental-buta, retardasi mentalkerusakan tulang-tulang, dan sebagainya) dimana kombinasi kelainan-kelainan tersebut menuntut suatu pelayanan pendidikan khusus yang berbeda dengan mereka yang mengalami kelainan yang bersifat tunggal (Cartwright dkk, dalam Mangunsong, 1998).

Menurut Buku Pedoman Umum Pelayanan Anak Cacat Ganda dan Majemuk, cacat ganda diartikan sebagai dua atau lebih kelainan dalam segi jasmani, keinderaan, mental, sosial, dan emosi, sehingga untuk mencapai perkembangan kemampuan yang optimal diperlukan pelayanan secara khusus dalam pendidikan, medik, dan sebagainya. Definisi lain memaparkan severe/multiple disabilities sebagai individu yang menun- jukkan ketidakmampuan fisik, sensoris, intelektual, dan atau kemampuan beradaptasi yang jauh berada di bawah ratarata norma individu normal dalam kriteria asesmen terhadap semua kemampuan tersebut (Hardman, Drew, \& Egan 1996).

Pada kenyataannya banyak orangtua para kelayan PACG tidak mampu lagi melaksanakan tugas mengasuh anak mereka yang menyandang cacat ganda sehingga tanggung jawab tersebut kemudian diserahkan pada para pengasuh di PACG. Oleh karena itu, pengasuhan para penyandang cacat ganda yang sebagian besar juga menyandang cerebral palsy tersebut tidak lagi berada dalam suasana sebuah keluarga, melainkan dijalankan sebagai tanggung jawab kerja oleh para pengasuh. Terkait dengan keberadaan PACG sebagai panti asuhan yang mengkhususkan diri mengasuh penyandang cacat ganda, profesi pengasuh di PACG menjadi unik bila dibandingkan dengan profesi pengasuh di panti asuhan yang pada umumnya mengasuh anak normal. Keunikan tersebut mendorong peneliti untuk menggunakan pendekatan kualitatif dalam penelitian ini.

Latar belakang pendidikan pengasuh di PACG rata-rata setingkat SMA dan mulai bekerja pada usia rata-rata 20 tahun. Para pengasuh di PACG umumnya tidak memiliki bekal profesional untuk berinteraksi dengan kelayan, terlebih kondisi kecacatan para kelayan menyulitkan komunikasi dan interaksi pengasuh dengan kelayan. Walaupun demikian, para pengasuh dituntut untuk dapat memahami kondisi tersebut sebagai situasi kerja utama yang harus mereka hadapi dalam menjalani pekerjaannya. Menurut Dariyo (2003), pemahaman dan pengetahuan yang baik mengenai situasi kerja merupakan bagian dari komponen kognitif yang akan mengarahkan perilaku dalam bekerja menuju pencapaian kepuasan kerja. 
Pekerjaan bukan hanya berperan sebagai sumber pemenuhan berbagai kebutuhan hidup yang mendasar, tetapi juga merupakan bagian dari identitas diri individu dewasa sekaligus wahana meraih prestasi dan mengaktualisasikan diri (Dariyo, 2003). Oleh karena itu, periode antara lulus SMA hingga sekitar usia 25 tahun dimana individu mulai bereksplorasi dan mengambil keputusan mengenai pekerjaan dan karier yang akan dijalani sepanjang hidupnya memiliki arti penting tersendiri. Pada kenyataannya tidak semua remaja memiliki kesempatan untuk memperoleh pelatihan dan atau pendidikan yang dapat membantu mereka mempersiapkan pekerjaan dan karier yang hendak dijalani. Mereka memperoleh pemahaman mengenai pekerjaan yang dijalaninya dengan mengalami langsung pekerjaan tersebut bersama pekerja yang telah lebih dulu menjalani pekerjaan yang mereka geluti. Kondisi demikian juga dialami para pengasuh di PACG.

Calhoun \& Acocella (1995) mendefinisikan penyesuaian diri sebagai interaksi individu yang bersifat berkesinambungan dengan diri sendiri, dengan orang lain, maupun dengan lingkungan tempat individu tersebut berada. Interaksi antara diri sendiri, orang lain dan lingkungan bersifat konstan dan timbal balik, sehingga ketiganya saling mempengaruhi. Definisi lain dikemukakan Atwater (1983) yang merumuskan penyesuaian diri sebagai perubahan-perubahan pada diri dan lingkungan di sekitar individu yang dibutuhkan dalam rangka meraih kepuasan hubungan dengan orang lain dan dengan lingkungan tempat individu tersebut berada. Definisi ini mengandung tiga faktor penyesuaian diri, yaitu diri sendiri, orang lain, dan terjadinya perubahan-perubahan.

Davis \& Lofquist (dalam Griffin \& Hesketh, 1999) mendefinisikan istilah penyesuaian diri dalam bekerja sebagai kecocokan antara individu dengan lingkungan kerjanya sebagai hasil interaksi antara karakteristik pribadi individu, dengan sejumlah atribut dalam pekerjaan yang dijalaninya. Dalam pengertian yang lebih mendetail, penyesuaian kerja dapat dimaknai sebagai penyesuaian antara kemampuan diri individu yang bersangkutan terhadap pekerjaan itu sendiri, terhadap jam-jam atau waktu kerja, terhadap personel lain, teman kerja, dan atasan, terhadap lingkungan dimana dia bekerja, serta terhadap adanya pertentangan antara minat-minat pribadi dengan perintahperintah resmi atasan yang mungkin dialami (Mappiare,1983).

Berdasarkan seluruh definisi tersebut, dapat disimpulkan bahwa penyesuaian diri dalam bekerja adalah hubungan saling pengaruh antara karakteristik pribadi individu dengan kriteria pekerjaannya yang menyebabkan individu tersebut melakukan serangkaian usaha penyesuaian terhadap cara pelaksanaan tugas-tugas dalam pekerjaannya, terhadap individu-individu lain yang terlibat dalam pekerjaannya, serta terhadap perubahan-perubahan yang terjadi dalam pelaksanaan pekerjaan tersebut agar individu yang bersangkutan dapat melaksanakan tugas dan pekerjaan yang diembannya dengan baik.

Hurlock (2004) memandang penting bahwa penyesuaian diri dalam bekerja, yang disebutnya dengan istilah penyesuaian kerja, yang harus dilakukan dalam ketiga kawasan berikut:

a. Pilihan pekerjaan

Penyesuaian pertama yang harus dilakukan individu dalam menjalani penyesuaian kerja adalah memilih bidang yang cocok dengan bakat, minat, dan faktor psikologis lainnya agar kesehatan mental dan fisiknya dapat terjaga.

b. Penyesuaian diri dengan pekerjaan Setelah memilih suatu pekerjaan, individu yang bersangkutan harus 
melakukan penyesuaian antara karakteristik pribadinya dengan sifat pekerjaan tersebut yang meliputi jenis kerja tiap hari dan minggunya, teman sejawat dan para pimpinan, lingkungan tempat kerja, serta aturan yang berlaku selama waktu kerja.

c. Stabilitas pilihan pekerjaan

Penyesuaian lain dalam kawasan penyesuaian kerja yang harus dilakukan oleh individu adalah mempertahankan kemantapan pilihan pekerjaan. Kemantapan pemilihan jurusan atau spesifikasi kerja bagi individu bergantung pada pengalaman kerja, daya tarik pribadi terhadap pekerjaan, nilai yang terkandung pada pekerjaan yang dipilih, serta pengaruh pertambahan usia.

Walaupun penilaian terhadap suatu perilaku penyesuaian bukan merupakan sebuah harga mati karena bergantung pada faktor situasi dan nilai pengamat (Calhoun \& Acocella, 1995), namun keberhasilan penyesuaian diri individu dalam bekerja dapat dinilai berdasarkan tiga kriteria umum yang disarankan oleh Hurlock (2004), yaitu:

a. Prestasi Kerja

Prestasi kerja dapat menjadi salah satu kriteria penilaian penyesuaian kerja karena prestasi-prestasi kerja yang dicapai dapat mendatangkan kepuasan dan kegairahan terutama pada individu dewasa muda.

b. Perubahan Pekerjaan dengan Sukarela

Jumlah perubahan yang dilakukan seseorang terhadap bidang kejuruan atau pekerjaannya dapat menjadi kriteria kegagalan atau keberhasilan dalam penyesuaian kerja yang dijalaninya.

c. Kepuasan Kerja

Kriteria ketiga ini seringkali dianggap sebagai kriteria terbaik dalam penilaian penyesuaian kerja. Kepuasan kerja juga dipengaruhi faktor ekonomi yang berhubungan dengan gaya hidup.

Menurut Sundari (2005), secara ideal seseorang yang memegang pekerjaan atau jabatan tersebut dapat menunjukkan kriteria penyesuaian kerja sebagai berikut :

a. Menunjukkan kematangan perilaku kerja dalam memegang jabatan atau pekerjaan tersebut.

b. Merasa senang dan mencintai jabatan atau pekerjaannya.

b. Bercita-cita atau berusaha mencapai kemajuan setingkat demi setingkat dalam pekerjaan atau jabatannya itu.

Memperhatikan secara langsung kondisi penyandang cacat ganda, serta tuntutan pekerjaan dan tujuan pelayanan yang diberikan oleh para pengasuh di PACG menimbulkan ketertarikan peneliti untuk memahami bagaimana pengalaman penyesuaian diri para pengasuh dalam menjalani pekerjaan mulia tersebut. Pemahaman akan pengalaman dan situasi psikologis dalam bekerja pada para pengasuh di PACG hanya dapat diperoleh dari gambaran makna subjektif yang ditangkap individu dalam kesehariaannya. Walaupun seluruh pengasuh mengalami penyesuaian diri dalam bekerja, tetapi pengalaman penyesuaian diri itu dapat dialami dan dimaknai dengan cara yang berbeda-beda oleh masing-masing pengasuh tersebut. Oleh karena itu, peneliti menggunakan pendekatan fenomenologis dalam penelitian kualitatif ini.

Pertanyaan penelitian yang diajukan dalam penelitian ini adalah: Bagaimana penyesuaian diri dalam bekerja yang dialami oleh pengasuh di Panti Asuhan Cacat Ganda (PACG)? Bagaimana para subjek memutuskan memilih profesi pengasuh sebagai pekerjaan mereka? 
Bagaimana pengasuh di PACG berinteraksi dengan kelayan dan rekan kerja? Apa saja kesulitan yang dihadapi pengasuh PACG dalam melaksanakan pekerjaan mereka sehari-hari dan bagaimana usaha yang dilakukan untuk mengatasinya?

\section{METODE PENELITIAN}

Fokus penelitian ini adalah menggambarkan proses penyesuaian diri dalam bekerja yang dilakukan pengasuh di Panti Asuhan Cacat Ganda (PACG) "X" Semarang dalam melaksanakan tugas dan kewajiban seharihari untuk merawat dan mengasuh para penyandang cacat ganda yang tinggal di panti. Subjek dalam penelitian ini didapatkan dengan menggunakan metode sampel purposif berdasarkan kriteria berikut:

a) Bekerja sebagai pengasuh di Panti Asuhan Cacat Ganda "X" Semarang;

b) Bersedia menjadi subjek dalam penelitian ini yang dikukuhkan secara tertulis dalam surat pernyataan persetujuan menjadi subjek.

Profil ketiga subjek penelitian dapat dilihat dalam Tabel 1.

Tabel 1.

Profil Subjek Penelitian

\begin{tabular}{lccc}
\multicolumn{1}{c}{ Subjek } & 1 & 2 & 3 \\
\hline Usia & 40 tahun & 39 tahun & 22 tahun \\
\hline Pendidikan & SMA & SMPS & SMK \\
\hline Agama & Katholik & Islam & Katholik \\
\hline Tanggal & 28 & 16 & \\
masuk & Februari & Februari & 1 Juli 2008 \\
kerja & 1989 & 1991 & \\
\hline Status & Karyawan & Karyawan & Karyawan \\
& tetap & tetap & kontrak \\
\hline \multirow{5}{\text{Urutan}}{} & Anak & Anak & Anak \\
dalam & keempat & tunggal & pertama \\
keluarga & dari & & dari dua \\
& delapan & & bersaudara. \\
& bersaudara & & \\
\hline
\end{tabular}

Metode pengumpulan data yang digunakan dalam penelitian ini adalah wawancara semi terstruktur dan observasi.

\section{HASIL DAN PEMBAHASAN}

Penyesuaian diri dalam bekerja pada pengasuh di PACG pada intinya merupakan proses penyelarasan hubungan antar manusia yang hidup bersama dalam rumah PACG "X" Semarang, yaitu antara subjek dengan pimpinan, dengan rekan kerja, dengan para kelayan, serta dengan keluarga dan masyarakat di sekitar PACG yang didasari perasaan interpersonal dan etika kerja.

Berangkat dari esensi yang ditemukan dalam penelitian ini bahwa penyesuaian diri pengasuh dalam bekerja di PACG merupakan usaha penyelarasan hubungan interpersonal antara masing-masing pengasuh tersebut dengan orang-orang yang terkait dengan pekerjaan mereka, interaksi sosial yang harmonis merupakan kunci bagi para pengasuh untuk dapat menjalani pekerjaannya dengan baik. Interaksi sosial ialah hubungan antara individu yang satu dengan individu yang lain, antara individu dengan kelompoknya, serta antara satu kelompok dengan kelompok yang lain yang menimbulkan saling pengaruh atau hubungan timbal balik antara pihak-pihak yang berinteraksi (Walgito, 1994). Menurut Maslow (dalam Alwisol, 2005), cinta dan penghargaan dari sesama manusia merupakan kebutuhan yang mendorong terjadinya berbagai interaksi sosial individu dalam usaha mewujudkan eksistensinya sebagai umat manusia.

Bila dikaitkan dengan penelitian ini, tampak bahwa keharmonisan hubungan antarpribadi diperlukan untuk mencapai kesejahteraan kehidupan manusia dalam berbagai bidang, termasuk dalam pekerjaan. Esensi penelitian ini menunjukkan bahwa pengalaman penyesuaian diri masingmasing subjek dalam bekerja sebagai pengasuh diwarnai oleh kentalnya kebutuhan berafiliasi dengan semua orang yang terlibat dan berada di sekitar lingkung- 


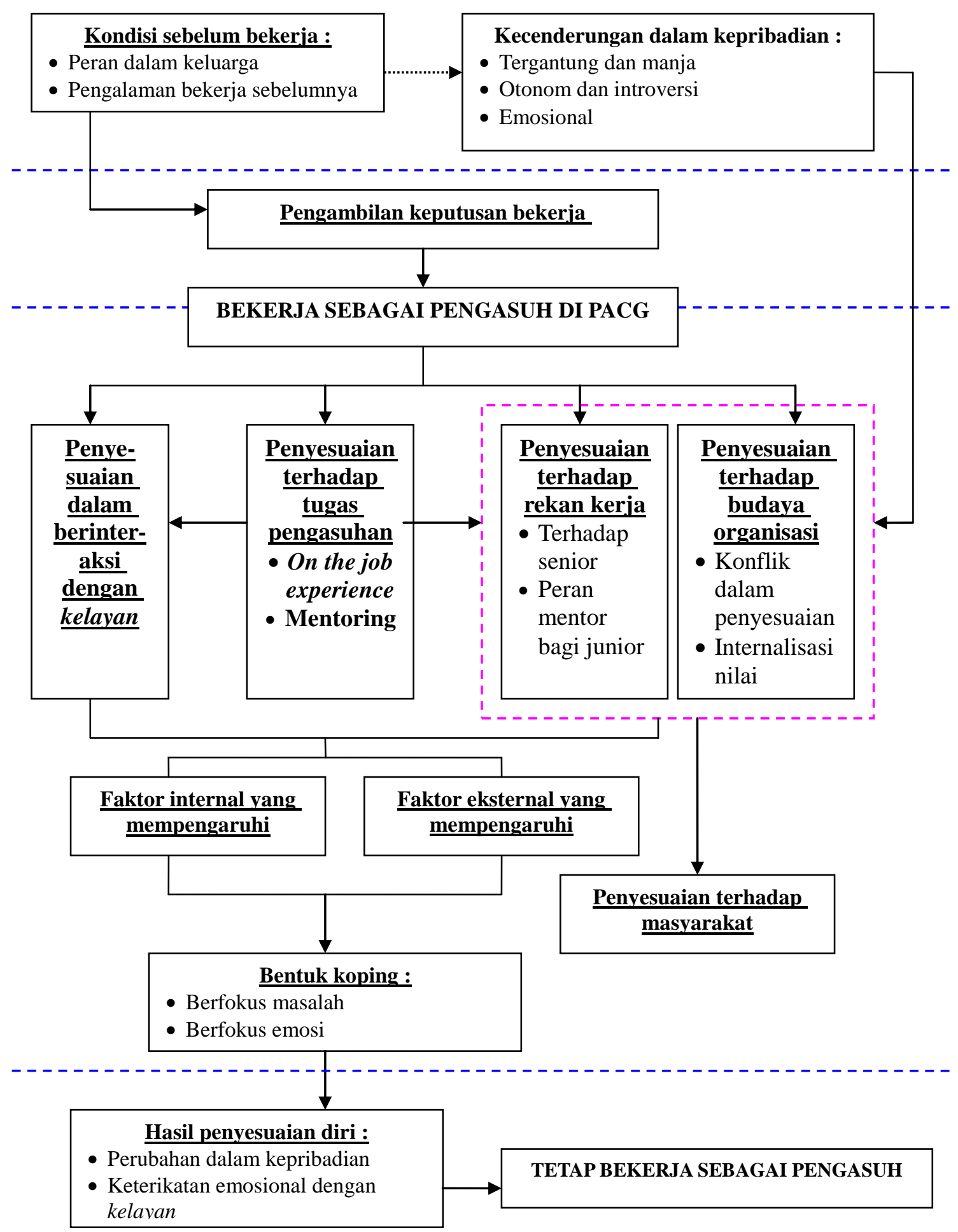

Gambar 1.

Keterkaitan unit-unit makna 
an kerja mereka, terutama para kelayan dan rekan kerja. Penyesuaian diri Subjek 1 termotivasi oleh penghargaan dari para kelayan dan rekan kerja, Subjek 2 melakukan usaha penyesuaian diri dengan mematuhi budaya organisasi dan otoritas tempat kerja demi penerimaan lingkungan kerja, sementara Subjek 3 sebagai karyawan baru berusaha meraih penghargaan sekaligus penerimaan dari kelayan dan rekan - rekan kerja melalui usaha penyesuaian dirinya.

Pada Gambar 1 ditampilkan bagan peta konsep untuk menggambarkan keterkaitan antar unit-unit makna yang ditemukan dalam dunia pengalaman subjek.

\section{Pemilihan pekerjaan}

Profesi pengasuh merupakan pekerjaan yang dijalani para subjek dengan disertai rasa keterpaksaan akibat minimnya kompetensi maupun kesempatan untuk memilih dan menjalankan pekerjaan lain. Schaiae dan Willis (2001) mengemukakan bahwa keluarga mempengaruhi pilihan pekerjaan individu melalui penyediaan kesempatan dan sarana pengembangan pribadi individu serta melalui proses sosialisasi status suatu pekerjaan, harapan orangtua, cita-cita, dan hasil kerja yang diharapkan.

Latar belakang kondisi keluarga para subjek menuntut para subjek mandiri dan bertanggung jawab dalam memilih dan menjalani pekerjaan mereka. Dikaitkan dengan keterpaksaan yang mengawali pilihan mereka atas profesi sebagai pengasuh di PACG, subjek berusaha mengembangkan suatu bentuk penerimaan diri sebagai wujud penyesuaian diri dalam bekerja.

Keadaan dalam keluarga tidak hanya menimbulkan dorongan untuk bekerja, namun juga turut berperan membentuk kecenderungan dalam kepribadian subjek yang ikut berkontribusi terhadap timbulnya stress, konflik, dan faktor-faktor yang mempengaruhi penyesuaian diri individu dalam menjalankan pekerjaannya kelak. Fakta ini peneliti temukan pada dinamika penyesuaian diri Subjek 1 dan Subjek 2. Penyesuaian diri yang dilakukan Subjek 1 dalam berinteraksi dengan rekan kerja menumbuhkan kesadaran untuk menghilangkan kecenderungan yang menurutnya tidak baik tersebut sehingga Subjek 1 mengalami tranformasi menjadi individu yang lebih yakin dan percaya diri dengan kemampuannya sendiri serta menjadi individu yang lebih bertang-gungjawab dalam mengelola kebutuhan dan menyelesaikan masalah yang dihadapinya.

Keadaan Subjek 1 berbeda dengan Subjek 2 yang merupakan anak tunggal. Kesendirian dalam keluarga sebagai anak tunggal terlebih karena kedua orangtuanya tinggal terpisah untuk merawat neneknya di desa, secara tidak langsung mengharuskan subjek untuk mampu menyelesaikan sendiri semua masalah yang dihadapinya. Kondisi tersebut juga membuat subjek cenderung mengembangkan introversi; subjek merasa susah menceritakan masalahnya pada orang lain dan sulit untuk bekerjasama dengan orang lain. Ciri ini menimbulkan kesulitan pada subjek dalam berinteraksi dengan orang-orang di lingkungan kerjanya.

\section{Penyesuaian terhadap Pilihan Pekerjaan}

Secara ideal, penyesuaian diri dalam bekerja pada kawasan pilihan pekerjaan dilakukan individu melalui pengumpulan informasi dan memahami tugas-tugas pekerjaan tersebut sebelum memutuskan untuk bekerja, demi tercapainya kesejahteraan jiwa dalam bekerja (Meichati, 1983). Hasil penelitian ini menunjukkan bahwa walaupun para subjek tidak memiliki pengetahuan yang memadai mengenai pengasuhan penyandang cacat ganda, 
dinamika penyesuaian kerja mereka menunjukkan tercapainya kesejahteraan psikologis dalam bekerja. Pencapaian tersebut tidak lepas dari proses mentoring sebagai cara utama subjek untuk belajar menguasai tugas-tugas pengasuhan.

Secara harfiah, mentor adalah seseorang yang lebih tua dalam arti lebih berpengalaman pada suatu bidang yang memandu individu di awal masa kerja untuk memberikan sosisalisasi profesionalitas dalam bekerja (Schaie dan Willis, 2001). Sebagai sebuah cara belajar untuk menguasai tugas-tugas pengasuhan yang menjadi tuntutan dalam bekerja, kegiatan mentoring dijalani para subjek dalam sistem on the job experience, yaitu semacam sistem pelatihan bagi para pekerja yang dijalani dengan langsung melaksanakan tugas-tugas pekerjaan tersebut (Schultz dan Schultz, 2002). Sistem on the job experience inilah yang menurut peneliti turut membantu pengasuh mengatasi konflik antara bayangan idealisme dengan kenyataan yang dihadapi dalam pekerjaan mereka.

Pengalaman Subjek 2 menunjukkan para rekan kerja senior yang berperan sebagai mentor bagi dirinya tidak hanya mengajarinya cara menjalankan tugas keseharian mengasuh para kelayan secara profesional, tetapi mereka juga berperan mendukung keberhasilan penyesuaian diri Subjek 2 terhadap budaya organisasi yang berlaku di PACG. Berkat dukungan para rekan kerja senior, subjek mampu mengikuti budaya kerja teamwork dan mengalami ekstraversi dalam berinteraksi sosial sebagai salah satu hasil penyesuaian diri yang dijalaninya tersebut.

Bentuk penyesuaian lain terhadap budaya organisasi yang juga dialami Subjek 2 adalah penyesuaian untuk mematuhi tata cara keagamaan di tempat kerja yang berbeda dengan agama yang dianutnya.
Dukungan dari rekan kerja senior yang seagama dengan subjek mendorong subjek untuk mengembangkan penerimaan dan kepatuhan terhadap aturan tersebut.

Penyesuaian terhadap budaya organisasi melalui mentoring juga dialami Subjek 3. Dalam penyesuaian ini pimpinan PACG berperan sebagai mentor yang menginternalisasi nilai-nilai kerja dan aturan pergaulan dalam bekerja dan tinggal di asrama PACG. Nilai-nilai tersebut merupakan bagian dari budaya organisasi yang dirumuskan secara umum oleh Robbins (2002) sebagai sistem makna bersama yang dianut oleh anggota-anggota organisasi tersebut untuk membedakannya dengan organisasi lain. Nilai-nilai kerja dan pergaulan dari pimpinan mempengaruhi pola interaksi subjek sebagai bentuk penyesuaian diri terhadap rekan kerja di PACG. Walaupun pimpinan PACG telah menyarankan subjek untuk mengemukakan secara terbuka hambatan yang dirasakannya kepada kedua rekan seniornya tersebut, nilai-nilai untuk mematuhi senior lebih melekat dalam diri Subjek 3.

Terkait posisi sebagai pengasuh terlama sekaligus dianggap sebagai pengasuh senior di PACG, Subjek 1 dan Subjek 2 mengalami penyesuaian diri dalam bekerja yang berbeda dengan Subjek 3 khususnya dalam penyesuaian terhadap rekan kerja. Ketika awal bergabung untuk bekerja di PACG, seluruh rekan kerja kedua subjek tinggal di asrama. Penyesuaian diri Subjek 1 dan Subjek 2 terhadap rekan kerja selanjutnya lebih didominasi penyesuaian diri dalam menjalankan peran sebagai mentor bagi para pengasuh baru yang merupakan rekan kerja juniornya. Walaupun kedua subjek bukan pemimpin di PACG, namun sikap mereka terhadap para rekan juniornya telah menunjukkan sebagian ciri kepemimpinan transformasional yaitu berusaha memberikan rangsangan intelektual dan mendukung perkembangan bawahan dalam 
tugas sekaligus memberikan perhatian yang bersifat personal (Robbins, 2002).

Bentuk penyesuaian yang paling penting dalam pengalaman penyesuaian diri untuk bekerja sebagai pengasuh di PACG adalah penyesuaian dalam berinteraksi dengan para kelayan. Kondisi kecacatan ganda para kelayan yang diasuh di PACG merupakan situasi sekaligus tantangan kerja utama yang harus dihadapi oleh para pengasuh. Subjek 1 dan Subjek 2 mendasarkan interaksi mereka dengan para kelayan pada perasaan empati. Sikap atau perasaan empati (emphatic concern) adalah perasaan simpati dan perhatian terhadap orang lain untuk berbagi pengalaman atau secara tidak langsung merasakan penderitaan orang lain (Sears, Freadman, \& Peplau, 1994).

Kedua subjek terdorong untuk bekerja sebagai pengasuh karena merasa kasihan sekaligus memendam curiosity atas kondisi dan perasaan para kelayan yang hidup dengan menyandang kecacatan ganda. Sikap empati dan perhatian para subjek ini menunjukkan kualitas yang diharapkan dari pendamping bagi penyandang cacat ganda yang menurut Nur'aeni (1997) harus dapat menyesuaikan dan memenuhi kebutuhan penyandang cacat dengan perhatian, sabar, penuh kasih, dan rajin memotivasi perkembangan mereka.

Kesulitan utama sekaligus tantangan dalam mengasuh yang dihadapi para subjek tidak terlepas dari kebutuhan khusus para kelayan. Menurut Subjek 3, tantangan yang dihadapinya adalah terbentuknya kesan pertama bahwa kenakalan kelayan dapat membahayakan orang lain di sekitarnya; sedangkan penolakan salah seorang kelayan serta situasi saat ada kelayan yang jatuh sakit hingga harus dirawat inap merupakan pencetus stres pengasuhan bagi Subjek 1 .

Sarafino (1994) mendefinisikan stres sebagai suatu keadaan yang muncul ketika transaksi antara individu dengan lingkungan menyebabkan individu merasakan ketidaksesuaian, baik secara nyata maupun tidak, antara tuntutan-tuntutan situasi dan sumbersumber daya sistem biologis, psikologis, atau sosial. Stres pengasuhan memiliki lima ciri kekhasan tersendiri yang meliputi kondisi anak, kondisi kehidupan menyeluruh pengasuh, dukungan sosial, fungsi keluarga, sumber material (Satiadarma, 2004). Berbeda dengan konsep stres pengasuhan dalam keluarga, stres pengasuhan pengasuh di PACG merupakan bentuk stres kerja dalam sebuah institusi. Oleh karena itu, sikap proaktif menghadapi penolakan kelayan serta dukungan rekan kerja melalui teamwork membantu subjek menghadapi stressor tersebut.

\section{Bentuk koping}

Kesulitan-kesulitan yang dialami para subjek dalam bekerja memunculkan strategi koping yang beragam sesuai situasi yang mereka hadapi dan kemampuan yang dapat mereka gunakan. Stress pengasuhan yang dialami Subjek 1 memungkinkannya untuk menggunakan strategi koping berfokus masalah karena Subjek 1 meyakini kemampuan yang ada pada dirinya dapat digunakan untuk mengubah situasi stressful karena penolakan, kondisi kelayan yang sakit beruntun, dan ketidakmampuan komunikasi dengan kelayan melalui sikap proaktif, ketekunan observasi, empati, dan teamwork yang solid dengan rekan-rekan kerja. Subjek 2 dan Subjek 3 mengembangkan koping berfokus pada emosi karena Subjek 2 tidak mampu mengubah situasi kerja yang menekankan pada teamwork dan mendasarkan aturan kerja pada tata cara ibadah yang berbeda dengan keyakinannya, sedangkan Subjek 3 tidak dapat mengubah urutan senioritas untuk terbebas dari kewajiban menghormati rekan senior. Subjek 2 memilih cara sharing dengan frater dan rekan seagama untuk mendukung langkah mematuhi aturan 
agama, Subjek 3 memilih diam dan menuruti semua perintah rekan seniornya.

\section{Stabilitas pilihan pekerjaan}

Penyesuaian diri dalam bekerja yang dilakukan ketiga subjek membuahkan hasil yang menunjukkan kemiripan, yaitu terjadinya perubahan dalam kepribadian dimana para subjek lebih menerima pekerjaan sebagai pengasuh. Perubahan yang terjadi meliputi peningkatan kontrol emosi, peningkatan kepercayaan diri, peningkatan self-esteem dalam bekerja, serta ekstraversi dalam berinteraksi sosial. Perubahan tersebut diakui para subjek mereka alami karena interaksi yang intensif dengan rekan kerja, para kelayan penyandang cacat ganda, serta sebagai bentuk penyesuaian terhadap budaya organisasi.

Berdasar pengalaman Subjek 1 dan Subjek 2, peneliti menemukan salah satu faktor eksternal yang mempengaruhi proses penyesuaian diri mereka dalam bekerja setelah menikah adalah diterimanya dukungan sosial dari keluarga serta orangorang yang terkait dengan pekerjaan mereka.

Secara umum, hasil penyesuaian diri para subjek dalam bekerja pada penelitian ini menunjukkan kriteria keberhasilan penyesuaian diri dalam bekerja sebagaimana dikemukakan oleh Sundari (2005). Perubahan yang berarah positif dalam kepribadian menunjukkan kema-tangan perilaku para subjek dalam bekerja, sedangkan keterikatan emosional yang terjalin antara para subjek dengan kelayan menunjukkan kecintaan para subjek terhadap pekerjaannya. Kriteria terakhir yaitu usaha mencapai kemajuan dalam bekerja tercermin dari kemauan para subjek untuk belajar menguasai tugas-tugas pengasuhan.

\section{KESIMPULAN}

Secara umum para subjek melakukan penyesuaian diri dalam bekerja sebagai pengasuh melalui serangkaian usaha agar mereka dapat diterima dan dihargai oleh rekan kerja, kelayan, serta masyarakat yang terkait dengan PACG sebagai lingkungan kerja mereka. Para subjek juga melakukan serangkaian usaha untuk dapat mengikuti aturan dan nilai-nilai kerja sebagai bagian budaya organisasi yang diterapkan di PACG.

Saat melaksanakan tugas pengasuhan sehari-hari di PACG, interaksi dengan rekan kerja dan kelayan merupakan bagian terpenting. Namun demikian, rangkaian pengalaman penyesuaian diri dalam berinteraksi dengan kelayan serta usaha penyesuaian untuk menguasai tugas-tugas pengasuhan membantu para subjek untuk lebih memahami karakteristik masingmasing kelayan dan cara mengasuh serta memenuhi kebutuhan mereka.

Kesulitan-kesulitan yang dihadapi para subjek dalam bekerja sebagai pengasuh cukup beragam sesuai keunikan pengalaman penyesuaian diri yang mereka lakukan. Untuk mengatasi kesulitankesulitan tersebut, para subjek menggunakan strategi koping yang disesuaikan dengan kemampuan mereka untuk mengubah keadaan selain juga dipengaruhi oleh sejumlah faktor-faktor internal yang berasal dari diri mereka dan faktor-faktor eksternal yang berasal dari lingkungan di sekitar subjek.

Para subjek mengalami perubahan dalam kepribadian menuju pada pribadi yang lebih menerima konsekuensi profesi mereka sebagai pengasuh. Perubahan ini merupakan hasil usaha penyesuaian diri yang mereka lakukan dalam bekerja. 


\section{DAFTAR PUSTAKA}

Alwisol. (2005). Psikologi kepribadian. edisi revisi. Malang: UMM Press.

Atwater, E. (1983). Psychology of adjustment: Personal growth in a changing world. New Jersey: Prentice Hall Inc.

Calhoun, J. F. \& Acocela J. R. (1995). Psikologi tentang penyesuaian dan hubungan manusia. edisi kelima. Penerjemah Satmoko, R. S. dan Su'udi, A. Semarang: IKIP Semarang Press.

Dariyo, A. (2003). Psikologi perkembangan dewasa muda. Jakarta: PT. Widiasarana Indonesia.

Griffin, B., \& Hesketh, B. (1999). Career development and counseling: Putting theory and research to work. New Jersey: John Wiley and Sons, Inc.

Hardman, M. L, Drew, C. J., \& Egan, M. W. (1996). Human exceptionality: Society, school, and family. Boston: Alyn and Bacon.

Hurlock, E. (2004). Psikologi perkembangan: Suatu pendekatan sepanjang rentang kehidupan. Edisi Kelima. Jakarta: Penerbit Erlangga.

Mangunsong, F. (1998). Psikologi dan pendidikan anak luar biasa. Jakarta : LPSP3 Universitas Indonesia.

Mappiare, A. (1983). Psikologi orang dewasa. Surabaya : Usaha Nasional.

Meichati, S. (1983). Kesehatan mental: Dasar-dasar praktis bagi pengetahuan dan kehidupan bersama. Bimo Walgito (ed). Yogyakarta:
Yayasan Penerbitan Fakultas Psikologi UGM.

Nur'aeni. (1997). Intervensi dini bagi anak bermasalah. Jakarta: Rineka Cipta.

Parminder, R., O'Donnell, M., Rosenbaumm, P., Brehaut, J., Walter, S. D., Russell, D., Awinton, M., Zhu, B., \& Wood, E. (2005). The health and well-being of caregivers of children with cerebral palsy, Pediatrics, 115(6), 626-636.

Robbins, S. P. (2002). Perilaku organisasi. Jilid 1. Penerjemah: Pujaatmaka, H., \& Molan, B. Jakarta: PT Indeks kelompok Gramedia.

Satiadarma, M. (2004). Mewaspadai stress pengasuh. Artikel dalam Bunga rampai Psikologi Perkembangan dari anak sampai usia lanjut. Editor: Singgih D. G. Jakarta: BPK Gunung Mulia.

Sarafino, E. P. (1994). Health psychology: Biopsychosocial interaction. Second Edition. New York: John Wiley \& Sons, Inc.

Schaie, K. W., \& Willis, S. L. (2001). Adult development and aging. Third Edition. New York: Harper Collins Publishing.

Schultz, D., \& Schultz, S. E. (2002). Psychology and work today. Ninth Edition. Upper Sadle River

Sears, D. O., Freedman, J. L., \& Peplau, L. A. (1994). Psikologi sosial. Jilid 2. Alih bahasa Michael Adryanto. Jakarta: Penerbit Erlangga.

Sundari, S. (2005). Kesehatan mental dalam kehidupan. Jakarta: Rineka Cipta. 
Tim Penyusun. (1995). Kamus Besar Bahasa Indonesia. Edisi Kedua. Jakarta: Balai Pustaka.
Walgito, B. (1994). Psikologi sosial: Suatu pengantar. Edisi Revisi. Yogyakarta: Andi Offset. 